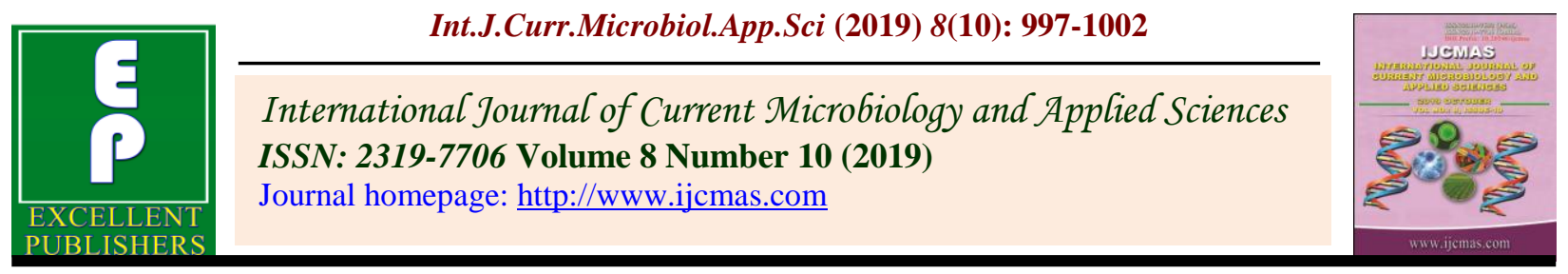

\title{
Correlation Studies of Quality Traits and Yields of Fodder Obtained from Intercropping Systems under Tarai Region of Uttarakhand, India
}

\author{
Sapana Tiwari ${ }^{1}$, Brajkishor Prajapati ${ }^{2 *}$ and Kewalanand ${ }^{1}$ \\ ${ }^{1}$ Department of Agronomy, College of Agriculture, GBPUA\&T, Pantnagar-263145, India \\ ${ }^{2}$ Department of Agronomy, KVK, Balaghat, M.P., India \\ *Corresponding author
}

\section{A B S T R A C T}

\section{Keywords}

Correlation, Crude protein content, Digestible dry matter content, Hemicellulose

\section{Article Info}

\section{Accepted:}

10 September 2019

Available Online:

10 October 2019
The experiment was conducted during rabi season of 2016-17 at Fodder Agronomy block of Instructional Dairy Farm (IDF), Nagla of the Govind Ballabh Pant University of Agriculture and Technology, Pantnagar, Udham Singh Nagar, Uttarakhand, India to correlation study between quality traits and yields of fodder obtained from intercropping systems. Randomized block design was used with four replications consisting of 10 treatments as detailed in materials and methods. The analysis of data indicated that dry matter content was positively correlated with cell wall contents. All cell wall structural components (NDF/ADF/hemicellulose) showed positive correlation with each other. There existed negative association with RFV, TDN, cell content, crude protein content $(\mathrm{CP})$ and dry matter intake (DMI). N content, CP content and DMI showed significant negative correlation with NDF and hemicellulose but positive association with DMD and RFV. The cell content showed significant negative correlation with cell wall components and positive association with $\mathrm{N}$ content, $\mathrm{CP}$ content and DMI. DMD was non significantly and positively associated with RFV, $\mathrm{N}$ content, $\mathrm{CP}$ content and DMI while significantly and positively association with TDN. DM content was positively correlated with all yields (GFY, DFY, DDMY, CPY) and this association was significant. NDF was positively associated with GFY, DFY and DDMY but significantly negative with CPY.

\section{Introduction}

Fodder plays a crucial role in the health and nutrition of the large population of livestock in India, which is having 11.6 per cent livestock population of the world (Ahmad et al., 2019), whereas milk production of the country is about 165.4 million tonnes in 2016-17. At present, the country faces a net deficit of $63 \%$ green fodder, $24 \%$ dry crop residues and $64 \%$ feeds, respectively (Choudhary et al., 2014). The available cool season forages are poor in quality, being deficient in available energy, protein and minerals. Therefore to compensate the low productivity of the livestock, farmers maintain a large herd of animals. Hence the milk production in country can be increased by providing nutritive fodder having good quality. Fodder yield and quality of crops are a complex cause of several effects and 
influenced by many component traits. Thus, study of correlation provides an opportunity to assess the magnitude and direction of association between yield and quality with its direct and indirect components, which are essential for formulating an effective and efficient crop improvement scheme (Chandra et al., 2012). To improve the quality and yield of fodder crops, it is imperative to know the association of different quality traits with the yield traits of fodder crops. In this view, the present study was undertaken to identify interrelationship of quality traits and their association with the yield and quality traits of fodder.

\section{Materials and Methods}

The experiment was conducted during rabi season of 2016-17 at Fodder Agronomy block of Instructional Dairy Farm (IDF), Nagla of the Govind Ballabh Pant University of Agriculture and Technology, Pantnagar, Udham Singh Nagar, Uttarakhand, India. The Instructional Dairy Farm is situated in the Tarai belt of Shivalik range of Himalayas with humid sub-tropical type of climate at latitude of $29^{\circ} \mathrm{N}$ and longitude of $79.3^{\circ} \mathrm{E}$ and situated at an altitude of $243.84 \mathrm{~m}$ above the mean sea level. The soil of experiment site was silty clay loam neutral in reaction $(7.58 \mathrm{pH})$ with $0.79 \%$ organic carbon, 281.45, 21.64 and $231.74 \mathrm{~kg} / \mathrm{ha}$ available $\mathrm{N}, \mathrm{P}$ and $\mathrm{K}$ respectively. The experiment was laid out in randomized block design with four replications and comprising ten treatments i.e. sole ryegrass, sole oat, sole barley, sole berseem, ryegrass+berseem (1:1), ryegrass+berseem (2:2), oat+berseem (1:1), oat+berseem (2:2), barley+berseem(1:1) and barley+berseem (2:2). The recommended fertilizers viz. 120:60:40 Kg N: $\mathrm{P}_{2} \mathrm{O}_{2}: \mathrm{K}_{2} \mathrm{O} / \mathrm{ha}$ for sole ryegrass, oat and barley, 20:60:40 Kg $\mathrm{N}: \mathrm{P}_{2} \mathrm{O}_{2}: \mathrm{K}_{2} \mathrm{O} /$ ha for sole berseem and 80:60:40 $\mathrm{Kg} \mathrm{N}: \mathrm{P}_{2} \mathrm{O}_{2}: \mathrm{K}_{2} \mathrm{O} / \mathrm{ha}$ for intercropping systems, respectively were applied. In basal application, half nitrogen was applied in sole ryegrass, oat, barley and intercropping system crops. Remaining nitrogen was top dressed in two equal splits after first and second cuttings. In legume crops, whole nitrogen was applied as basal. Total amount of recommended phosphorus (i.e. $60 \quad \mathrm{Kg} \quad \mathrm{P}_{2} \mathrm{O}_{2} / \mathrm{ha}$ ) and potassium (i.e. $40 \mathrm{Kg} \mathrm{K}_{2} \mathrm{O} / \mathrm{ha}$ ) were applied at the time of sowing in all crops. The harvested herbage was weighted immediately for green fodder yield and $500 \mathrm{~g}$ fresh sample from each net plot was taken to determine dry matter content. The samples were dried at $70^{\circ} \mathrm{C} \pm 2$ in hot air oven for moisture loss, grounded with a Wiley mill to pass through $1 \mathrm{~mm}$ screen and analyzed for quality components. Total $\mathrm{N}$ was determined using the CHNS analyzer and crude protein was calculated by multiplying nitrogen per cent with 6.25 (AOAC, 1965). Total digestible nutrients (TDN), digestible dry matter (DDM), dry matter intake (DMI) and relative feed value (RFV) were estimated according to the following equations adapted from Horrocks and Vallentine (1999): TDN= $(-1.291 \mathrm{X} \mathrm{ADF})+101.35, \mathrm{DMI}=120 / \% \mathrm{NDF}$ dry matter basis, DDM=88.9-(0.779 X \% $\mathrm{ADF}$, dry matter basis), RFV=\% DDM X \% $\mathrm{DMI} X 0.775$. The data was subjected for correlation study as per procedure given by Cochran and Snedecor (1994).

\section{Results and Discussion}

\section{Correlation among quality parameters}

NDF had significant positive association with ADF, hemicellulose and dry matter content. However non significant positive association with DM content was noticed. It was negatively correlated with DDM, RFV, TDN, cell content, nitrogen, CP content and DMI. This was significant for cell content, nitrogen, CP content and DMI (Table 1). ADF had significant negative correlation with DDM, TDN, cell content and DMI. This might be due to the fact that the accumulated cell wall 
contents are always less digestible than cell soluble and also cell wall contents simply act as physical barrier to microbial enzymes reacting their target polysaccharides (Chesson, 1993). Thus digestibility, cell content and intake are reduced with the presence of cell wall components and negative correlation existed (Prajapati et al., 2017). Hemicellulose had non significant positive correlation with DDM indicating better digestibility of hemicelluloses than ADF/NDF. Hemicellulose had significant negative association with cell content, nitrogen content, $\mathrm{CP}$ content and DMI. RFV was non significantly and negatively associated with cell wall components (ADF, NDF and hemicellulose) and for other parameters it had non significant positive association. A significant positive correlation of TDN with DDM and significant negative correlation with ADF was noticed. Inverse relationship between TDN and ADF was reported by Lithourgidis et al., (2006). Cell content showed significant negative correlation with cell wall contents (NDF/ADF/Hemicellulose). The cell wall is formed by the transport of cell contents viz. sugar matrix components from the golgibodies that are the sugar donors for cell wall component viz. hemicellulose, cellulose, fibers, lignin etc (Taiz and Zeiger, 2002). Thus if cell wall contents increases, the cell content decreases showing a negative correlation between cell wall and cell contents. Nitrogen content had significant positive association with CP content, DMI and cell content. There existed negative correlation between ADF, NDF, hemicellulose and TDN but it was significant for NDF and hemicellulose. Association between nitrogen content and cell content, CP content, DMI was significant and positive. Chandra et al., (2012) also reported positive association between $\mathrm{N}$ content and $\mathrm{CP}$ content. DMI was significantly and positively associated with cell content, nitrogen content, $\mathrm{CP}$ content while significantly and negatively associated with ADF, NDF and hemicellulose.
Earlier workers have also observed negative association between DMI and cell wall components (Ayan et al., 2012).

\section{Quality parameters and yield}

The correlation between quality parameters and yield as presented in (Table 2) indicated that DM content was positively correlated with all yields (GFY, DFY, DDMY, CPY) and this association was significant. Enhancement in dry fodder yield is due to accumulation of dry matter in various plants parts which increases the weight. This factor might have led significant positive correlation with green /dry forage yield (Chandra et al., 2012). The DDMY also had significant positive correlation with dry matter content which might be due to higher values of dry matter and digestible dry matter. The association between CPY and dry matter content was positive but non significant. Crude protein content was negatively associated with GFY, DFY and DDMY and this association was non significant. Crop yielding higher dry matter has been reported to have lower crude protein (Fageria and Baligar, 2005; Ibraham et al., 2006) this might be a reason for negative correlation between CPY and total fodder yields. However, crude protein content had significant positive association with crude protein yield. Higher values of crude protein content and DFY lead to enhancement in CP yield. Similar was the association between nitrogen content and various yields since CPY is a function of nitrogen content in the plants and thus positive correlation was observed. A positive association between $\mathrm{CP}$ content, DMY and CPY in cereal-legume intercropping has been noticed by (Ram and Singh, 2003). A non significant positive association between TDN and yields was noticed. This suggests that accumulation of digestible nutrients was more with increase in green /dry fodder yield and there by more DDMY and CPY. 
Table.1 Correlation study between different quality parameters.

\begin{tabular}{|c|c|c|c|c|c|c|c|c|c|c|}
\hline Quality Parameters & NDF & ADF & DDM & Hemicellulose & RFV & TDN & Cell content & Nitrogen & $\mathbf{C P}$ & DM \\
\hline ADF & $0.680^{*}$ & & & & & & & & & \\
\hline DDM & $-0.598^{\mathrm{NS}}$ & $-0.941^{* *}$ & & & & & & & & \\
\hline Hemicellulose & $0.685^{*}$ & $0.055^{\mathrm{NS}}$ & $0.095^{\mathrm{NS}}$ & & & & & & & \\
\hline RFV & $-0.484^{\mathrm{NS}}$ & $-0.544^{\mathrm{NS}}$ & $0.364^{\mathrm{NS}}$ & $-0.336^{\mathrm{NS}}$ & & & & & & \\
\hline TDN & $-0.236^{\mathrm{NS}}$ & $-0.702^{*}$ & $0.809^{* *}$ & $0.546^{\mathrm{NS}}$ & $0.102^{\mathrm{NS}}$ & & & & & \\
\hline Cell content & $-1.000^{* *}$ & $-0.681^{*}$ & $0.595^{\mathrm{NS}}$ & $-0.689^{*}$ & $0.487^{\mathrm{NS}}$ & $0.230^{\mathrm{NS}}$ & & & & \\
\hline Nitrogen & $-0.872^{* *}$ & $-0.309^{\mathrm{NS}}$ & $0.204^{\mathrm{NS}}$ & $-0.935^{* *}$ & $0.452^{\mathrm{NS}}$ & $-0.245^{\mathrm{NS}}$ & $0.873^{* *}$ & & & \\
\hline $\mathbf{C P}$ & $-0.881^{\text {** }}$ & $-0.310^{\mathrm{NS}}$ & $0.216^{\mathrm{NS}}$ & $-0.923^{* *}$ & $0.415^{\mathrm{NS}}$ & $-0.218^{\mathrm{NS}}$ & $0.882^{* *}$ & $0.998^{* *}$ & & \\
\hline DM & $0.408^{\mathrm{NS}}$ & $0.067^{\mathrm{NS}}$ & $-0.053^{\mathrm{NS}}$ & $0.515^{\mathrm{NS}}$ & $-0.055^{\mathrm{NS}}$ & $0.225^{\mathrm{NS}}$ & $-0.404^{\mathrm{NS}}$ & $-0.527^{\mathrm{NS}}$ & $-0.519^{\mathrm{NS}}$ & \\
\hline Dry matter intake & $-0.967^{\text {** }}$ & $-0.651^{*}$ & $0.565^{\mathrm{NS}}$ & $-0.657^{*}$ & $0.385^{\mathrm{NS}}$ & $0.238^{\mathrm{NS}}$ & $0.968^{* *}$ & $0.837^{* *}$ & $0.851^{* *}$ & $-0.481^{\mathrm{NS}}$ \\
\hline
\end{tabular}

$\mathrm{NDF}=$ Neutral detergent fiber, $\mathrm{ADF}=$ Acid detergent fiber, $\mathrm{DDM}=$ Digestible dry matter, $\mathrm{RFV}=$ Relative feed value, $\mathrm{TDN}=\mathrm{Total}$ digestible nutrient, $\mathrm{CP}=\mathrm{Crude}$ protein, DM= Dry matter, DMI = Dry matter intake; * and ** Significant at $5 \%$ and $1 \%$ level, respectively

Table.2 Correlation study between quality parameters and yields

\begin{tabular}{|l|c|c|c|c|}
\hline \multirow{2}{*}{ Quality Parameters } & \multicolumn{3}{c|}{ Yield (q/ha) } \\
\cline { 2 - 5 } & GFY & DFY & DDMY & CPY \\
\hline NDF & $0.396^{\mathrm{NS}}$ & $0.342^{\mathrm{NS}}$ & $0.400^{\mathrm{NS}}$ & $-0.669^{*}$ \\
\hline ADF & $-0.010^{\mathrm{NS}}$ & $-0.043^{\mathrm{NS}}$ & $0.047^{\mathrm{NS}}$ & $0.395^{\mathrm{NS}}$ \\
\hline DDM & $-0.018^{\mathrm{NS}}$ & $0.013^{\mathrm{NS}}$ & $0.048^{\mathrm{NS}}$ & $-273^{\mathrm{NS}}$ \\
\hline Hemicellulose & $0.442^{\mathrm{NS}}$ & $0.414^{\mathrm{NS}}$ & $0.550^{\mathrm{NS}}$ & $0.568^{\mathrm{NS}}$ \\
\hline RFV & $-0.078^{\mathrm{NS}}$ & $-0.029^{\mathrm{NS}}$ & $0.156^{\mathrm{NS}}$ & $0.015^{\mathrm{NS}}$ \\
\hline TDN & $0.140^{\mathrm{NS}}$ & $0.165^{\mathrm{NS}}$ & $0.285^{\mathrm{NS}}$ & $0.676^{*}$ \\
\hline Cell content & $-0.387^{\mathrm{NS}}$ & $-0.333^{\mathrm{NS}}$ & $-0.393^{\mathrm{NS}}$ & $0.659^{*}$ \\
\hline Nitrogen & $-0.486^{\mathrm{NS}}$ & $-0.441^{\mathrm{NS}}$ & $-0.545^{\mathrm{NS}}$ & $0.671^{*}$ \\
\hline CP & $-0.481^{\mathrm{NS}}$ & $-0.435^{\mathrm{NS}}$ & $-0.526^{\mathrm{NS}}$ & $0.263^{\mathrm{NS}}$ \\
\hline DM & $0.921^{* *}$ & $0.930^{* *}$ & $0.924^{* *}$ & $0.601^{\mathrm{NS}}$ \\
\hline DMI & $-0.423^{\mathrm{NS}}$ & $-0.370^{\mathrm{NS}}$ & $-0.392^{\mathrm{NS}}$ & \\
\hline
\end{tabular}

$\mathrm{NDF}=$ Neutral detergent fiber, $\mathrm{ADF}=$ Acid detergent fiber, $\mathrm{DDM}=$ Digestible dry matter, RFV $=$ Relative feed value, $\mathrm{TDN}=\mathrm{Total}$ digestible nutrient, $\mathrm{CP}=\mathrm{Crude}$ protein, DM= Dry matter, DMI= Dry matter intake, GFY=Green fodder yield, DFY=Dry fodder yield, DDMY= Digestible dry matter yield, $\mathrm{CPY}=\mathrm{Crude}$ protein yield; * and ** Significant at $5 \%$ and $1 \%$ level, respectively. 
RFV was positively correlated with CPY and DDMY however, negative association with GFY and DFY. RFV is a function of DDMY and DMI (Albayrak et al., 2011). NDF was positively associated with GFY, DFY and DDMY but significantly negative with CPY. ADF was negatively correlated with all the yields except DDMY. Hemicellulose content was negatively associated with CPY but positively with GFY, DFY and DDMY. Significant negative association between $\mathrm{NDF} / \mathrm{ADF}$ and $\mathrm{CP}$ has been reported earlier too.

On the basis of the present investigation, it is concluded that all cell wall structural components (NDF/ADF/hemicellulose) showed positive correlation with each other. There existed negative association with RFV, TDN, cell content, crude protein content (CP) and dry matter intake (DMI). DMD was positive correlation with RFV, TDN, cell content, $\mathrm{N}$ content, crude protein content (CP) and dry matter intake (DMI). Hence, associated effects between cereals and legumes may improve quality traits of fodder and their relation with yields.

\section{References}

Ahmad, S., Kour, G., Singh, A. and Gulzar, M. 2019. Animal genetic resources of India - An overview. International Journal of Livestock Research. 9(3): 112.

Albayrak, S., Turk, M., Yüksel, O. and Y1lmaz, M. 2011. Forage yield and the quality of perennial legume-grass mixtures under rainfed conditions. Notulae Botanicae Horti Agrobotanici Cluj-Napoca. 391: 114-118.

AOAC 1965. Official methods of analysis. $10^{\text {th }}$ ed. Association of official Agricultural Chemicals. Washington, DC, USA.

Ayan, I.H., Mut, H., Basaran, U., Acar, Z. and
Onal Asci, O. 2012. Forage potential of cowpea (Vigna unguiculata L. Walp). Turkish Journal of Field Crops. 17(2): 135-138.

Chandra, R., Kewalanand, Joshi, Y.P. and Singh, S. 2012. Correlation studies in multicut forage sorghum grown under different environments. Forage Research. 37(4): 263-265.

Chesson, A. 1993. Mechanistic models of forage cell wall degradation. In H.G. Jung, D.R. Buxton, R.D. Hatfield, and J. Ralph, eds. Forage Cell Wall Structure and Digestibility. ASA-CSSA-SSSA, Madison, WI, USA. p. 347-376.

Choudhary, K.K., Yadava, N.S., Yadav, S.L. and Jat, R.C. 2014. Green fodder yield and quality of barley (Hordeum vulgare L.) as affected by levels of nitrogen. Forage Research. 39: 190-196.

Cochron, G.W. and Snedecor, W.G. 1994. Statistical methods, 8th ed. Oxford and IBH Publication CO. Pvt. Ltd. Calcutta.

Fageria, N.K. and Baligar, V.C. 2005. Enhancing nitrogen use efficiency in crop plants. Advances in Agronomy. 88: 97-185.

Horrocks R.D. and Vallentine, J.F. 1999. Harvested forages, Academic Press, London, UK, pp. 17-47.

Ibrahim, M., Rafiq, M. and Sultan, A. 2006. Green fodder yield and quality evaluation of maize and cow pea sown alone and in combination. Journal of agricultural research. 44(1): 15-21.

Lithourgidis, A.S., Vasilakoglou, I.B., Dhima, K.V., Dordas, C.A. and M.D. Yiakoulaki. 2006. Forage yield and quality of common vetch mixtures with oat and triticale in two seeding ratios. Field Crops Research. 99: 106-113.

Prajapati, B., Bhatnagar, A. and Kewalanand. 2017. Quality analysis of winter season forage crops. Forage Research. 42(4): 252-257.

Ram, S.N. and Singh, B. 2003. Physiological 
growth parameters forage yield and nitrogen uptake of sorghum as influenced with legume intercropping, harvesting time and nitrogen level. Indian Journal of Agronomy. 48(1): 38-
41.

Taiz, L. and E. Zeiger, 2002. Plant Physiology. $3^{\text {rd }}$ Edition Published by Sinauer Associates, Inc. Sunderland, U.S.A. 623 p.

\section{How to cite this article:}

Sapana Tiwari, Brajkishor Prajapati and Kewalanand. 2019. Correlation Studies of Quality Traits and Yields of Fodder Obtained from Intercropping Systems under Tarai Region of Uttarakhand, India. Int.J.Curr.Microbiol.App.Sci. 8(10): 997-1002.

doi: https://doi.org/10.20546/ijcmas.2019.810.116 